\title{
CORRELATION OF THE BASAL GRETACEOUS BEDS OF THE SOUTHEASTERN STATES
}

\author{
ВУ Wrтне Сооке
}

\section{SUMMARY}

The basal Cretaceous deposits that fringe the inner margin of the Coastal Plain from eastern Alabama to central North Carolina, where they are overlapped by Miocene sands, have been commonly classified as of Lower Cretaceous age and correlated roughly with the Patuxent formation of the Potomac group of Maryland and Virginia. In this paper the evidence on which this early correlation was based is reviewed, later evidence is considered, and the conclusion is reached that all the basal Cretaceous deposits in the area under consideration are of Upper Cretaceous age.

Acknowledgments are gratefully made of the helpful criticism of the manuscript by L. W. Stephenson and of his generous assistance in the preparation of the correlation table.

\section{CURRENT CLASSIFICATION WITH THE LOWER CRETACEOUS}

In 1907 Stephenson ${ }^{1}$ applied the name "Cape Fear formation" to more or less arkosic and micaceous sands and clays in North Carolina which rest upon the irregularly eroded surface of the crystalline rocks and are separated from the next younger division, now called Black Creek formation, by a marked erosional unconformity. With regard to their correlation, he says:

No fossils have been found in these deposits. Upon lithologic and stratigraphic grounds the formation is believed to be approximately synchronous with the Patuxent division of the Potomac series of Maryland and Virginia, although it may include a portion of that series younger than the Patuxent proper.

A paper read by William Bullock Clark before the Geological Society of America in December, 1908, contains the following statement: ${ }^{2}$

Farther southward in North Carolina is the Cape Fear formation (arkosic sands, clays), so called by Stephenson, which is evidently continuous with the Patuxent formation, although the basal beds of the Coastal Plain are transgressed by later formations in southern Virginia and northern North Carolina. No fossils have been found in the Cape Fear formation, but the strata are similar lithologically to the Patuxent farther north and unlike the Arundel and Patapsco.

In later papers Stephenson was induced to abandon the use of the name "Cape Fear" in favor of Patuxent, although there is abundant internal evidence that he was not convinced of the synchroneity of the "Cape Fear" and the Patuxent formations.

\footnotetext{
1 Stephenson, L. W., Some facts relating to the Mesozoic deposits of the Coasta Plain of North Carolina: Johns Hopkins Univ. Cir., new ser., No. 7, pp. 93-99, 1907. 2 Geol. Soc. America Bull, vol. 20, p. 647, 1910.

In December, 1910, Stephenson wrote the following statement ${ }^{3}$ for the "Index to the stratigraphy of North America":

The basal portion of the Cretaceous deposits in the region included between the Roanoke Valley in North Carolina and the Alabama Valley in Alabama is composed of highly crossbedded arkosic sands, in general of coarse texture, with subordinate interbedded layers and lenses of light-colored clays of greater or less purity, reaching an estimated maximum thickness of 500 or 600 feet. These have been designated the "Cape Fear" formation in North Carolina by the writer and the "Hamburg beds" in South Carolina by Earle Sloan and have been regarded as the eastward continuation of the Tuscaloosa (Upper Cretaceous) by the Georgia and Alabama geologists.

In the Carolinas these beds are separated from the overlying Black Creek formation by an unconformity. Likewise an unconformity separates them from the overlying Eutaw formation in the Chattahoochee and Alabama river regions in Georgia and Alabama. Geographically the belt in which the deposits occur is separated from the Cretaceous occurrences to the northward in Virginia by an overlap of Miocene beds. However, in all their physical characters they bear a close resemblance to the Patuxent formation, which forms the basal division of the Potomac group in Virginia and Maryland. On account of this physical similarity and because of their supposed buried connection with the Virginia Patuxent, the application of the name Patuxent has been extended to include these North Carolina arkosic beds. The apparent continuity of the North Carolina beds with the similar deposits to the south would, in the absence of known unconformities, seem to necessitate the adoption of the name Patuxent for all the beds in question in South Carolina, Georgia, and Alabama, unless biologic evidence indicating the incorrectness of this interpretation is forthcoming. With one exception no organic remains have been found in these arkosic beds south of the Virginia line. A few poorly preserved plant remains have been collected recently from an exposure in a bluff of Tallapoosa River at Old Fort Decatur, in Macon County, Ala. These were submitted to E. W. Berry, who expressed the opinion that the beds containing them are of Lower Cretaceous age. The meager paleontologic evidence thus afforded tends to confirm conclusions which Mr. Berry and the writer had previously reached, based on physical criteria alone. Unfortunately the poorly preserved condition of the leaves renders it difficult to determine satisfactorily the relation of the formation to the Patuxent formation of Virginia and Maryland. However, in Mr. Berry's opinion, the presence of large numbers of leaves, apparently dicotyledons, most of which are too poorly preserved to permit their specific or even generic determination, seems to justify doubt as to their being as old as the Patuxent formation, in which similar questionably identified dicotyledons are very sparingly represented.

In 1914 Stephenson added: ${ }^{4}$

Should future discoveries confirm the doubt expressed by Berry as to the Patuxent age of the Lower Cretaceous beds

3 U. S. Geol. Survey Prof. Paper 71, pp. 605-606, 1912.

4 Stephenson, L. W., Cretaceous deposits of the eastern Gulf region: U. S. Geol. Survey Prof. Paper 81, p. 11, 1914. 
of Alabama and Georgia, and should it be found that the Alabama-Georgia Lower Cretaceous deposits are synchronous with the "Cape Fear" formation, it would at once become apparent that the name Patuxent was not appropriate for Lower Cretaceous deposits anywhere south of Virginia.

\section{EVIDENCE OF UPPER CRETACEOUS AGE}

My own field work in South Carolina during 1917 and 1922, part of which was done in company with $\mathrm{Mr}$. Stephenson, led me to the opinion that the supposed Lower Cretaceous deposits of South Carolina are really of Upper Cretaceous age. With this in mind, Mr. Stephenson, in 1923, revisited Old Fort Decatur, Ala., and obtained additional collections of fossil plants which, when studied by Professor Berry, proved to be of Upper Cretaceous age, probably of about the age of the Tuscaloosa formation of westerncentral Alabama. ${ }^{5}$ This removes the only paleontologic barrier to the correlation of the basal Cretaceous deposits of the States south of Virginia with the Upper Cretaceous and restores the original correlation made by the Alabama Geological Survey.

$\mathrm{My}$ reason for thinking that the basal Cretaceous deposits of South Carolina are of Upper Cretaceous age is this: There seems to be no valid distinction between the so-called Lower Cretaceous or "Hamburg beds" of Sloan and the typical Middendorf beds, which contain a large flora of Upper Cretaceous age. ${ }^{6}$ Middendorf lies in the midst of uniform sand hills that extend from the North Carolina line along the southern border of the Piedmont upland to the valley of Congaree River at Columbia. No one has succeeded in separating the "Hamburg" from the Middendorf in this area. The type area of the "Hamburg" is on the east side of Savannah River opposite Augusta and is obviously the continuation of the so-called Lower Cretaceous of Georgia. The lithology in the two areas is very similar.

The Middendorf beds, named by Sloan in $1904,{ }^{7}$ were described ten years later by Berry ${ }^{8}$ under the name "Middendorf arkose member of the Black Creek formation." Berry considered the Middendorf a member of the Black Creek because a good many species of plants are common to the two, but in my opinion the differences in the floras are more significant than the resemblances. Of the 65 species from the Middendorf listed by Berry, 39 have not been found in the Black Creek formation in the Carolinas. Stronger evidence that the Middendorf should be considered an independent formation is afforded by. the stratigraphy and areal distribution. The Middendorf consists chiefly of light-gray, white, or buff crossbedded arkosic sand and lenses of white or light-col-

\footnotetext{
${ }^{5}$ Berry, E. W., The age of the supposed Lower Cretaceous of Alabama: Wash. ington Acad. Sci. Jour., vol. 13, pp. 433-435, 1923.

6 Berry, E. W., Upper Cretaceous and Eocene floras of South Carolina and Georgia: U. S. Geol. Survey Prof. Paper 84, 1914.

${ }^{7}$ Sloan, Earle, A preliminary report on the clays of South Carolina: South Carolina Geol. Survey, ser. 4, Bull. 1, p. 75, 1904.

8 Berry, E. W., op. cit. (Prof. Paper 84), p. 7.
}

ored clay or kaolin that contrast sharply with the overlying black or very dark clay and sand of the typical Black Creek, from which they are separated by a pronounced unconformity. The area occupied by the Middendorf is much greater than that of the Black Creek in South Carolina, and the type locality of the Middendorf, which lies near the center of its belt of outcrop, is 20 miles from the nearest exposure of the Black Creek formation. It seems fitting, therefore, to restore the Middendorf to the rank of formation. The name Middendorf formation can also be applied to the "Hamburg beds" and to the equivalent "undifferentiated Upper Cretaceous" deposits ${ }^{9}$ (formerly called Lower Cretaceous) east of Flint River in Georgia. However, some of the beds in Georgia having the aspect of the Middendorf may be considerably younger than the typical Middendorf of South Carolina. The basal Cretaceous deposits of South Carolina and Georgia, as well as those of Alabama, are therefore of Upper Cretaceous age.

Concerning the basal Cretaceous of North Carolina Stephenson ${ }^{10}$ says:

Although the "Cape Fear beds" appear to be continuous with the Lower Cretaceous arkosic beds of South Carolina [Middendorf formation], Georgia, and Alabama, it is possible that they are not actually continuous; for the irregular character of the bedding, the presence of numerous local unconformities within the beds, and the lack of extensive exposures render the detection of an important unconformity difficultand such an unconformity may exist.

The discovery that the Middendorf lies unconformably below the Black Creek formation, like the "Cape Fear" formation, is additional evidence that the "Cape Fear" and the Middendorf are of the same age. However, there are certain rather obvious differences in lithology between the beds in North Carolina and those in South Carolina. The beds of the "Cape Fear" formation in their best exposures along Cape Fear River are persistent and generally compact and uniform, but those of the Middendorf formation are variable, lenticular, and usually softer. Yet beds resembling the "Cape Fear" occur at several places in South Carolina, notably at Eureka Mill Pond, 5 miles southwest of Cheraw, and near the Cheraw-Camden road 2 miles west by south of Patrick. At the type locality of the Middendorf formation the plant-bearing clay bed merges into tough argillaceous gray sand resembling the typical "Cape Fear." It seems certain that the "Cape Fear" and the Middendorf are at least in part equivalent.

The following hitherto unpublished note on the "Cape Fear" formation is contributed by Mr. Stephenson:

On Little River, near old Manchester, on the northern edge of Camp Bragg, Cumberland County, N. C., there are exposures

\footnotetext{
- Prettyman, T. M., and Cave, H. S., Petroleum and natural gas possibilities in Georgia: Georgia Geol. Survey Bull. 40, pp. 75-76, 1923.
}

10 Stephenson, L. W., op. cit. (Prof. Paper 81), p. 11. 
of compact greenish-gray more or less sandy clay interbedded with compact argillaceous arkosic micaceous sand, hard enough, in fact, to be classed as a soft sandstone. These beds are harder and appear more ancient than the more typical "Cape Fear" sediments above them. It is possible that these harder beds may belong to a Cretaceous formation older than the overlying more typical unconsolidated beds of the "Cape Fear," with which they have heretofore been included.

In view of the fact that the "Cape Fear" formation may include more than the Middendorf of South Carolina, it seems best to retain for the present the name "Cape Fear" rather than to extend the use of the name Middendorf, which has priority, to all of the "Cape Fear" of North Carolina. However, the name Middendorf doubtless eventually will be applied to the corresponding deposits in North Carolina. In the light of the present known facts, the name Patuxent obviously can not appropriately be used in North Carolina.

\section{PREFERRED CORRELATION}

The precise correlation of the Middendorf with formations west of Flint River can not yet be stated with assurance. Florally, the Middendorf in South Carolina is most closely related to the Tuscaloosa formation, 21 of its 65 species of fossil plants being present also in the Tuscaloosa, whereas only 9 are common to the Eutaw; but as some of the common species have a long range and wide distribution, the number of significant species is less than the figures given. It seems probable that in Georgia the beds having a Middendorf aspect represent a period of time somewhat longer than that of the Tuscaloosa and including part, perhaps all, of Eutaw time. These relations are indicated in the subjoined correlation table, which is based chiefly upon the work of Stephenson.

Correlation of the Upper Cretaceous formations of the Southeastern States

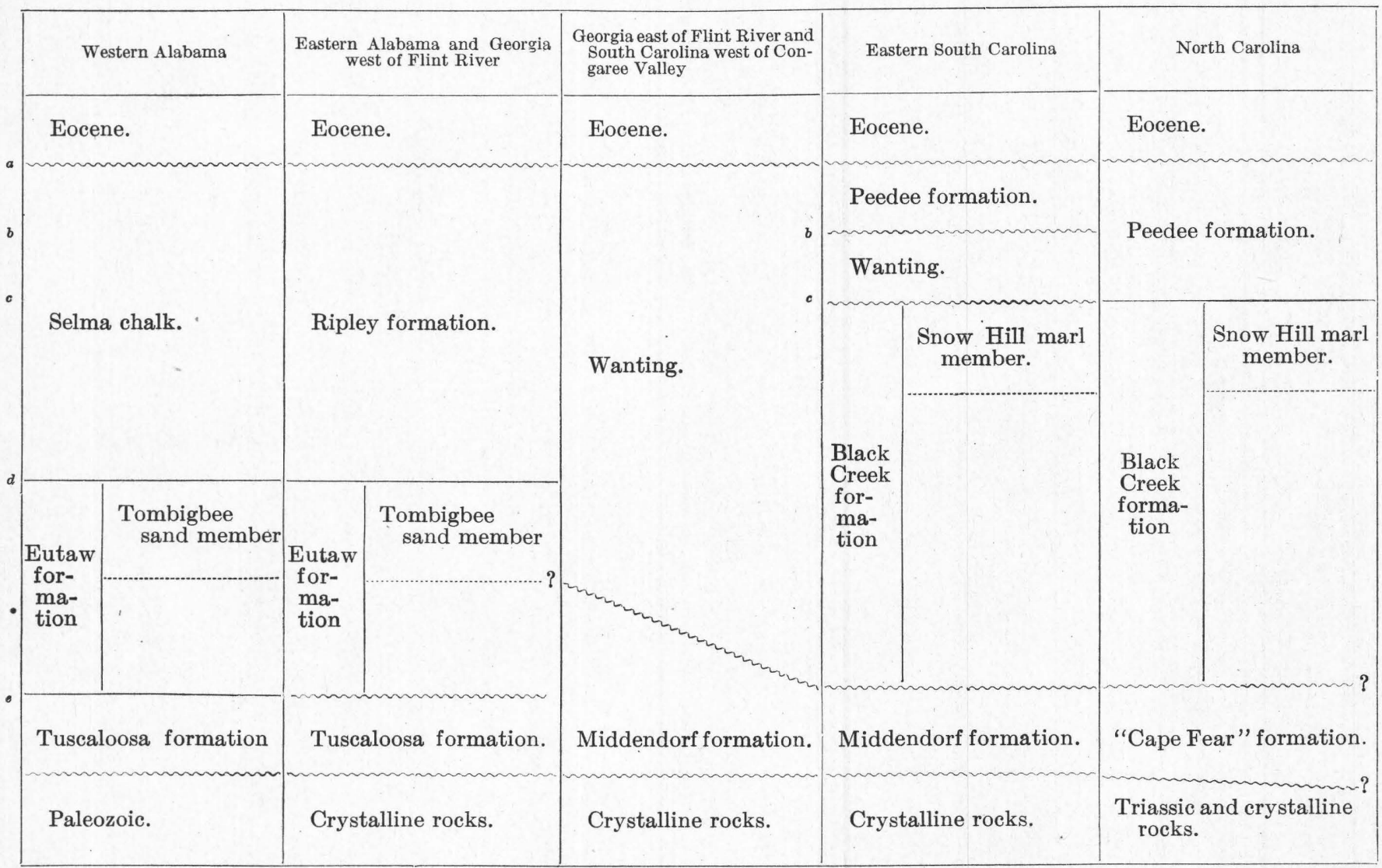

a. Top of Exogyra costata zone.

$b$. Top of Exogyra cancellata subzone.

c. Base of Exogyra costata zone and Exogyra cancellata subzone and tep of Exogyra ponderosa zone.

d. Top of Mortoniceras subzone; the base is not definitely established but appears to be restricted within the Tombigbee sand member of the Eutaw formation.

$e$. Exogyra upatoiensis zone. This zone has not been found in outcrop in the Carolinas but has been recognized near the bottom of a 2,000 -foot well at Charleston. 